Diverse Parties, Diverse Agendas? Female Politicians and the Parliamentary Party's Role in Platform Formation

\author{
Zachary Greene, Ph.D. \\ Lecturer \\ University of Strathclyde, Glasgow, Scotland \\ zacgreene@gmail.com \\ Diana Z. O’Brien, Ph.D. \\ Assistant Professor \\ Indiana University, Bloomington, Indiana \\ dzobrien@indiana.edu
}




\begin{abstract}
Parties' parliamentary delegations contain a multitude of interests. While scholars suspect that this variation affects party behavior, most work on parties' policy statements treats parties as unitary actors. This reflects the absence of strong expectations concerning when (and how) the parliamentary caucus matters for platform construction, as well as the difficulties inherent in testing such claims. Drawing on the literature on women's descriptive representation, we argue that the makeup of the parliamentary party likely has important consequences for issue entrepreneurship, the scope of issues represented on the manifesto, and even the left-right position of election platforms. With the most comprehensive party-level study of women's representation ever conducted, we test our three diversity hypotheses using data on the gender makeup of parties' parliamentary delegations and the content of their manifestos for 110 parties in 20 democracies between 1952 and 2011. We show that as the percentage of women in the parliamentary party increases, parties address a greater diversity of issues in their election campaigns. Women's presence is also associated with more leftleaning manifestos, even when controlling for parties' prior ideological positions. Together, these findings illustrate a previously overlooked consequence of descriptive representation and provide a framework for understanding when and why the parliamentary party influences manifesto formation. They show that diversity-or lack thereof-has important consequences for parties' policy statements, and thus the overall quality of representation.
\end{abstract}

KEYWORDS: political parties; intra-party politics; women and politics; party manifestos; election campaigns 
Parties bring together a multitude of interests within a single organization. Politicians represent a range of electoral districts, possess distinct backgrounds and personal characteristics, and hold a broad set of issue priorities and preferences (e.g Esaiasson 2000; Narud and Valen 200; Norton 1999; Thomassen and Andeweg 2004). Members of parliament, moreover, believe that these unique perspectives have implications for the form and content of political representation. They argue that changing the membership of the parliamentary delegation alters parties' policy agendas. These claims are especially prevalent in the debates surrounding efforts to bolster the presence of historically underrepresented groups in elected office. Arguments in favor of increasing women's numeric (or descriptive) representation, for example, suggest that doing so will bring new experiences, viewpoints, and topics into the policy formation process (e.g. Kittilson 2008, 2010).

While politicians claim that the makeup of the parliamentary delegation matters for the quality of representation, scholars remain divided on this front. On the one hand, a large body of normative literature argues that the election of women and minorities facilitates the policy representation of group interests (e.g. Mansbridge 1999; Williams 2000; Young 2002). These claims find support in empirical studies linking descriptive and substantive representation (Kittilson 2008, 2010; Xydias 2007). The effect of individual MPs' preferences in parliamentary systems, on the other hand, has been of comparatively little interest to party politics researchers. Although scholars suspect that intra-party variation shapes parties' behavior (e.g. Bernauer and Bräuninger 2009; Ceron 2012 and 2013; Debus and Bräuninger 2008; Greene and Haber 2014; Greene and Jensen 2014; Schumacher et al. 2013), existing studies have yet to generate strong theoretical or empirical expectations about parliamentarians' role on this front. To the contrary, most work treats parties as unitary actors and ascribes policy shifts to electoral motivations (e.g. Adams et al. 2006; Adams and Somer-Topcu 2009; Ezrow 2008; Ezrow et al. 2011; Hellwig 2012; Laver and Shepsle 1996; Tavits 2007; Williams et al. 2014). 
Drawing on wide-ranging normative and empirical literatures-which rarely speak to one another-we help to resolve these seemingly contradictory claims by explicitly linking the makeup of the parliamentary party to election platform formation. As the public face of their parties, we recognize that MPs shape platforms by offering new ideas and providing parties with the credibility necessary to attend to particular issues. Though this influence has proved exceptionally difficult to observe, we argue that when parties include a broader and more diverse set of viewpoints within the parliamentary delegation, this likely influences their willingness to campaign on new issues and to emphasize a greater range of topics on their election platforms. The composition of the parliamentary caucus may even affect the party's left-right position.

To test for these diversity effects, we focus on the relationship between women's representation and the content of election platforms in 110 parliamentary parties from 20 OECD countries between 1952 and 2011. Examining the impact of women's descriptive representation offers an ideal test for our theory. A large normative and empirical literature posits that women bring distinct preferences and perspectives to the policymaking process. These claims, moreover, are central to academic and "real world" debates concerning measures like gender quotas for candidate lists. Evidence that gender composition influences the content of parties' policy statements would thus provide insights into the importance of diversity within parliamentary delegations, while also adding to our knowledge of the effects of descriptive representation on policy change.

With our original and expansive dataset, we consider the likelihood that a party 1) innovates on a topic not previously politicized in the country, 2) presents a broader set of issues on its platform, and 3) shifts its left-right position. We show that organizations with more female MPs present more topically diverse platforms and move their positions leftwards. In demonstrating that the makeup of the parliamentary delegation can broaden (or narrow) the content and scope of the manifesto, we shed light on a neglected factor influencing platform construction. We also draw 
attention to an overlooked by-product of increasing women's presence in elected office. Taken together, these findings indicate that diversity—or lack thereof-has important consequences for the overall quality of representation.

In the following sections, we first identify two accounts of parliamentarians' roles in shaping party behavior. We then bring together and extend this literature with three hypotheses linking parliamentary party diversity and election platform construction. We test these claims by examining the relationship between the presence of female MPs and issue entrepreneurship, platform breadth, and the left-right position of parties' agendas. We provide consistent evidence that the proportion of seats held by women has strong implications for parties' campaign messages. Based on these findings, we conclude by discussing women's representation and intra-party diversity as a missing link explaining policy change.

\section{COMPETING PERSPECTIVES ON PARTY BEHAVIOR}

Parties are the primary political actors in modern democracies. Party policy change is thus of major interest to those concerned with questions of democratic representation and accountability in these states, and a large body of work examines the factors shaping their policy statements. Parties have been shown, for example, to alter their left-right stances in response to shifts in public opinion (Adams et al. 2009). The magnitude of party change is influenced by previous electoral performances (Somer-Topcu 2009), and the degree of responsiveness further varies based on party type (Adams et al. 2006; Adams and Ezrow 2009; Ezrow et al. 2011; Spoon 2011), inter-party competition (Adams and Somer-Topcu 2009, Meguid 2008), intra-party dynamics (Ceron 2012 and 2013; Schumacher et al. 2013) and economic circumstances (Adams et al. 2009; Greene 2015; Hellwig 2012; Williams et al. 2014).

Between elections, parties alter not only their left-right location, but also the issues on which they focus. Though voters punish parties that change their positions on principled matters, parties 
can adjust their stances on more pragmatic policies (Tavits 2007). When they expect to benefit from campaigning on novel topics, parties also act as issue entrepreneurs (De Vries and Hobolt 2012). They focus on particular policies_-such as "green" concerns-based on electoral threat and opportunity (Spoon et al. 2013). Just as parties address different kinds of topics, the diversity of subjects included on their platforms also varies. Changes in the dispersion of voters' ideological preferences accompany comparable shifts in parties' policy positions, particularly in less proportional electoral systems (Ezrow 2007).

Together, these works tell us a great deal about parties' policy agendas. Like traditional theories of election strategy (e.g. Downs 1957; Petrocik 1996), however, they assume that parties behave as unitary actors. Despite this assumption's prevalence, parties clearly contain distinct groups that do not necessarily share the same interests, concerns, and aims. Growing evidence shows that intra-party blocs influence party decision-making and constrain leaders (Ceron 2012, 2013; Wiliarty 2013). Divisions within parties shaped institutional reforms in Japan (McElwain 2008), for example, and moderated broad party changes and coalition politics across Europe (Gianetti and Benoit 2008; Harmel and Janda 1994; Laver 1999). Internal divisions over policy strategy likewise dominate the campaigns of small parties (Spoon 2011). More generally, the balance-of-power between intra-party groups affects parties' responses to vote- and office-seeking incentives (Schumacher et al. 2013).

Existing research thus offers competing narratives: there is reason to treat parties as unitary actors, but growing evidence also shows that intra-party dynamics influence party behavior. This work remains comparatively silent, moreover, on the link between the composition of intra-party groups and parties' policy statements. There has been little theorizing, in particular, on the relationship between the makeup of the parliamentary party and the election manifesto. This is a surprising oversight given activists' and politicians' beliefs that the representation of social identities 
and territorial and functional interests within the parliamentary delegation matters for policy outcomes, as well as the direct and indirect roles MPs play in the agenda formation process.

The principal barrier in reconciling these perspectives is not the belief that either electoral motivations or the parliamentary delegation alone wholly explain party behavior; scholars accept the importance of both. Rather, the challenge is that it is unclear when - and in what ways - the makeup of the parliamentary party influences platform construction and how we can test for these effects. A solution to these challenges lies, we argue, in incorporating research on the representation of historically underrepresented groups into the party politics framework.

Arguments in favor of increasing the presence of traditionally marginalized groups in elected office often highlight the unique viewpoints held by group members (e.g. Mansbridge 1999; Phillips 1995; Williams 2000). These works posit that group representatives call on elements of their shared experiences with their constituents to explore possible ramifications of emergent issues and speak with authority on these matters. This suggests that the inclusion of these groups in the parliamentary party has observable implications for the form and content of parties' policy statements. Inspired by this literature, in the following section we theorize about parliamentarians' role in agenda construction and develop three hypotheses connecting the makeup of the parliamentary delegation to manifesto formation. To do so, we focus on an increasingly important marker of political diversity: the gender composition of the parliamentary party.

\section{THE EFFECTS OF DIVERSE PARLIAMENTARY PARTIES}

Despite the large literature on party manifestos, little systematic research considers their authorship. This largely reflects the tremendous variation in the procedures governing policy construction both across parties and within parties over time. Even during a single election, differences can emerge between the formal rules and informal norms governing platform creation. Like other intra-party 
affairs, party agenda formation is treated as a black box from which unified policy statements emerge.

Though manifesto authorship is understudied, there is reason to believe that parliamentarians play direct and indirect roles in this process. Among intra-party groups, parliamentarians disproportionately influence policy (Esaiasson and Holmberg 1996; Esaiasson 2000; Patzelt 1997, 1999; Thomassen and Andeweg 2004). In fact, policy positions often emerge from intense debates within parliamentary party groups (Diaz 2005; Thomassen and Andeweg 2004). Parties' internal division of labor further strengthens parliamentarians' positions (Thomassen and Andeweg 2004). By accumulating specialized knowledge, rank-and-file MPs become leaders in particular fields and exercise considerable influence over party policy (Patzelt 1999; Searing 1994).

Consistent with this work, members of the parliamentary delegation often directly participate in policy construction. Consider, for example, the British governing parties' 2015 election manifestos. The Conservative Party's policy commissions included figures from the parliamentary party's 1922 Committee and MPs from the Number 10 Policy Board. Indeed, this latter body was established to incorporate parliamentarians' viewpoints into government policy. The Number 10 Policy Unit also featured several MPs. Parliamentarians likewise aided in the construction of the Liberal Democrats' manifesto. MPs were important figures on the party's central policymaking body, the Federal Policy Committee (FPC), and within its Manifesto Working Group. The FPC also consulted with the parliamentary party—as well as the party's policy working groups, which include MPs_-before finalizing the platform's content.

In addition to direct involvement, MPs also indirectly affect party policy. In many ways, parliamentarians are the lifeblood of they party: they interact with constituents, serve on policyoriented committees, campaign on its behalf, etc. Even when the leader and her closest advisers play an outsized role in manifesto authorship, rules and norms provide MPs with the access 
necessary to lobby ministers and articulate distinct viewpoints (Norton 1999; Thomassen and Andeweg 2004). Leaders, in turn, have incentives to address parliamentarians' policy ideas. In parliamentary systems, governing parties depend on MPs' loyalty to control the executive. MPs similarly play a role in intra-party leadership contests and influence the leader's tenure in office.

Legislators' characteristics are thus likely "important components of the input for parliamentary decision-making" (Cotta and Best 2007, 5). Indeed, the composition of the parliamentary delegation has already been shown to influence the issues parties include on their platforms (Kittilson 2010). Yet, establishing which MPs' characteristics matter-and in what ways the makeup of the parliamentary party influences manifestos—remains a significant challenge.

While rarely considered by party politics scholars, a large body of women and politics research suggests that the gender composition of the parliamentary delegation provides a promising point of departure for this work. Sex is an increasingly salient political identity; parties from across the ideological spectrum address women on their policy statements, court female voters, and even implement quota policies mandating the selection of female candidates based on the belief that women have unique political perspectives. Women's descriptive representation thus represents a key area in which scholars and politicians alike believe that the composition of the parliamentary delegation affects party behavior. Unlike other groups, moreover, women are present across countries and among all parties' supporters. This allows for the examination of diversity's effects across place and time. Using sex as an important marker of diversity, we focus on three ways in which women's presence in the parliamentary party likely influences platform construction.

\section{Issue Entrepreneurship}

Historical competencies, government participation, and public opinion each influence the issues parties include on their agendas (Spoon and Klüver 2014; Klüver and Spoon Forthcoming). Parties typically focus on issues important to their traditional constituencies and on which they are 
perceived as capable (Hibbs 1977; Petrocik 1996; Egan 2013). Electoral dynamics also play a role, as competition from new, issue-focused parties encourages mainstream organizations to address new policies (Meguid 2008; Spoon et al. 2013). In certain contexts, parties also use formerly neglected topics to seek out previously unmobilized supporters (Carmines and Stimson 1989). Acting as "issue entrepreneurs," they hope to benefit from campaigning on a new issue dimension on which party and voter preferences align (De Vries and Hobolt 2012; Schumacher et al. 2013).

Though previously overlooked, we posit that the parliamentary party can also play a role in issue entrepreneurship. Intra-party diversity may help parties identify latent topics and provide them with the motivation to address these subjects on their policy agendas. These effects are especially likely to emerge when members of the parliamentary caucus have distinct outlooks that they articulate during the policy formation process. In many institutions, female politicians in particular have been shown to offer unique viewpoints. Male and female parliamentarians sometimes express personal interests in different policy areas and address different issues in electoral campaigns (Wängnerud 2000). Female candidates in Westminster democracies, for example, have distinct attitudes concerning representation, economic conservatism, and social and moral traditionalism (Erikson 1997, Norris 1996). In Nordic states, (wo)men in parliament hold policy views similar to (wo)men in the electorate (Narud and Valen 2000). Even where men and women have broadly similar attitudes, male and female co-partisans conceive of "women's interests" differently (Xydias 2013) and have significantly different preferences with respect to affirmative action and gender equality (Lovenduski and Norris 2003; McAllister and Studlar 1992).

While there is no single "women's perspective," and not all female MPs differ from their male counterparts, in the aggregate male and female politicians have often been shown to both take different stances on the same issues and also to prioritize different policy areas. Though largely empirically untested, normative theorists further suggest that alternative perspectives are likely to be 
especially important when addressing "uncrystallized interests" (Mansbridge 1999). In these cases, representatives of traditionally marginalized groups call on elements of their shared experiences with their constituents to explore the ramifications of emergent issues and speak with the authority of experience on these matters. Increasing parliamentary party diversity may thus increase the probability that at least a subset of MPs can use their distinct worldviews to draw attention to new topics (including, but not limited to, those traditionally viewed as “women's issues”). Indeed, while descriptive representation does not necessarily alter policy outcomes, its effects are most likely to be felt in the agenda-setting phase of the policymaking process (Barnes 2016, Franceschet and Piscopo 2008, Kittilson 2010).

Even when female politicians neither perceive that they hold unique perspectives and priorities nor enter office with the intention of advocating on behalf of new policies (Bochel and Bochel 2008), their presence alone can reduce barriers to issue entrepreneurship. Risk adverse leaders avoid topics on which they have little previous experience. Greater parliamentary party diversity provides leaders with information that both highlights previously unidentified issues and reduces the uncertainty of addressing new topics. This suggests:

H1: Parties with a greater percentage of female MPs are more likely to act as issue entrepreneurs by including previously unaddressed topics on their policy platforms.

\section{Issue Breadth}

Parliamentary party diversity also likely affects the breadth of parties' statements. Theoretically, if parties held perfect information about the distribution of voters' issue priorities they could address only those topics on which they would attract more votes than their competitors (De Vries and Hobolt 2012). In practice, though the number of ideological dimensions in Western Europe decreased in the post-war era (Best 2011; Stoll 2010), the breadth of parties' agendas has generally increased over time (Greene 2015). Parties now aim to satisfy a broad range of objectives 
with the issues included on their manifestos. They hope to emphasize areas in which they are competent (e.g. Green and Jennings 2012), influence the scope of the election (Hellwig 2012; Wagner and Meyer 2014; Williams et al. 2014), indicate their desired cabinet portfolios (Bäck et al. 2011), and outline the policies they intend to pursue in office (Jennings et al. 2011; Thomson 2001).

Extending the logic of the first hypothesis, we argue that intra-party diversity provides incentives for including a wider range of issues on the manifesto. The inclusion of previously unidentified issues does not demand that parties remove other topics from their platforms. To the contrary, parties will continue to address these issues to appease voters and party members. Logically, the inclusion of both existing and emerging topics necessarily broadens the scope of parties' manifestos. Even in the absence of issue entrepreneurship, the wider range of perspectives provided by a more diverse parliamentary party likely expands leaders' attention to a broader set of issues. Indeed, if the party hopes to convert parliamentary delegation diversity into increased voteshare, it may feel obligated to reflect this diversity in its platform. In these cases, parties should provide a more extensive (and thus inclusive) manifesto to voters. Consequently, we expect:

H2: Parties with a greater percentage of female MPs discuss a greater number of issues on their policy platforms.

\section{Left-Right Positions}

Parties vary not only the content and scope of their platforms, but also their overall placement on the left-right spectrum. Indeed, the majority of research on parties' manifestos focuses on these left-right shifts. Studies show that parties alter their stances in response to public opinion (Adams et. al 2009), the economy (Hellwig 2012; Williams et al. 2014), recent and significant losses (Harmel and Janda 1994), competitors' positions (Adams and Somer-Topcu 2009; Meguid 2008; Somer-Topcu 2009), and their own experiences in government (Bawn and Somer-Topcu 2012). 
Though this work treats parties as unitary actors, a growing body of evidence suggests that intra-party relations influence these shifts. Leaders balance the goals of competing intra-party groups vis-à-vis pursuing pure policies versus winning office (Spoon 2011). Intra-party elections and decision-making bodies also limit leaders' ability to unilaterally set policy priorities and election strategies (Ceron 2012; Greene and Haber 2014; Harmel and Janda 1994; Lehrer 2012). The relative strength of party activists and leaders, for example, determines the degree to which parties respond to vote- and office-seeking aims (Greene and Jensen 2014; Schumacher et al. 2013). Internal factions even limit leaders' ability to maintain parliamentary discipline (Ceron 2013).

While it is clear that intra-party dynamics affect agendas, the parliamentary delegation's role in shaping its party's placement on the left-right dimension remains unknown. Building on the previous hypotheses, we expect that diversity has both direct and indirect consequences on this front. Diversifying the parliamentary delegation can lead to the incorporation of perspectives that diverge from the party's present position. Female parliamentarians in Western Europe, for example, tend to be to the left of both their male colleagues and male and female voters (Diaz 2005). This pattern holds for parties across the political spectrum. On average social democratic women are more likely than their male co-partisans to prioritize left-leaning social policy issues (Wängnerud 2000), just as female Conservative MPs are more likely than men to adopt progressive, feminist, and left-leaning positions (Childs and Webb 2012). The inclusion of women in the parliamentary delegation may thus move the party leftward.

Even if male and female parliamentarians view themselves as ideologically similar, women's presence may indirectly lead parties to present more left-leaning manifestos. Female politicians' preferences on gender equality policies tend to be to the left of their male colleagues (Lovenduski and Norris 2003; McAllister and Studlar 1992), and they are more likely to articulate these claims during parliamentary party group meetings (Erzeel 2015). This focus on more left-leaning issues is 
not restricted to explicitly gendered issues; in some cases female candidates are also more concerned about welfare services, poverty, and healthcare (Norris 1996). Unsurprisingly, women's presence in parliament correlates with governments' increased focus on some left-leaning policy areas (Annesley et al. Forthcoming; Kittilson 2008).

If responding to women's distinct issue priorities leads parties either to begin addressing leftleaning issues_-or to move their positions on existing policies slightly to the left—-then diversity will generate a leftward shift in their overall positions. In her study of parties' manifestos, for instance, Kittilson (2010) finds that parties with more female representatives place greater emphasis on social justice issues. A heightened focus on these policies should, in turn, pull parties to the left in the aggregate. We thus posit that diversity within the parliamentary delegation has knock-on effects for the platforms' placement on the left-right dimension. This suggests our final hypothesis:

H3: Parties with a greater percentage of female MPs will shift their ideological positions leftward.

\section{METHODS AND DATA}

We test our hypotheses by combining data on the gender composition and election manifestos of 110 parties in 20 OECD countries between 1952 and 2011. ${ }^{1}$ Our original dataset of

\footnotetext{
1 Our sample is primarily limited by the availability of data on the gender makeup of the parliamentary party. We include parties in the following countries: Australia (1969-2010), Austria (1971-2008), Belgium (1995-1999), Canada (1972-2011), Denmark (1968-2011), Finland (19662011), Germany (1972-2009), Greece (2004), Ireland (1969-2011), Japan (1967-2005), Luxembourg (1979-1999), Netherlands (1971-2010), New Zealand (1972-2011), Norway (1965-2005), Portugal (1979-2011), Spain (1979-2011), Sweden (1970-2010), Switzerland (1995-2011), the United Kingdom (1974-2010), and the United States (1952-2008).
} 
899 total observations includes the broadest set of parties and countries for which data could be located. It represents the most comprehensive party-level study of women's representation ever conducted.

As well as being unparalleled in their scope, our data also provide a difficult test for our theory in two important ways. First, mandate switching is comparatively less common in these countries than in other parts of the world (Thomson et al. 2012). Since parties usually implement their agendas when controlling office, they are likely to be selective about the policies included on their platforms. Second, while our sample includes a diverse set of parties and countries with a wide range of institutional rules, on average party unity is high and party leaders maintain strong control of the legislative agenda. These are the very circumstances in which we might expect women's presence to have the least effect on policy platforms. Consequently, evidence for our hypotheses in these countries increases our confidence that our results will hold in systems where parties are less cohesive and legislators have greater freedom to initiate policy.

\section{Outcome Variables: Operationalizing Issue Entrepreneurship, Breadth, and Left-Right Position}

To examine the relationship between women's descriptive representation and parties' policy statements, we use Comparative Manifestos Project (CMP) data (Budge et al. 1998; Klingemann et al. 2006; Volkens et al. 2011) to develop three outcome variables directly related to our hypotheses. The CMP measures the percentage of statements parties include on their manifestos in 56 different policy arenas, which we collapse into 42 non-directional issues (Greene 2015). When examining issue entrepreneurship, we focus on the first dimension of de Vries and Hobolt's (2012) definition, emphasizing the "party strategy of active mobilization of new policy issues that have been largely ignored by the political mainstream" (250). To capture this phenomenon, we created an indicator 
variable that denotes whether the party was the first in the country to address a new policy domain. ${ }^{2}$ This is a conservative measure of issue entrepreneurship that focuses on major policy innovations in one of our 42 distinct domains, such as human rights, education and social justice. ${ }^{3}$ According to our data, for example, the German Free Democratic Party introduced the anti-imperialism topic into the electoral arena for the first time in 1976. Prior to that election, no other German manifesto included this issue area—which captures negative references to "imperial behavior" (Volkens et al. 2011).

To capture issue diversity, we examine the scope of parties' policy statements (Greene 2015). In particular, we consider the number of issues that parties include in their election manifestos. Focusing again on the 42 CMP policy areas, we calculate the relative number of issues in parties' platforms with a measure of entropy commonly used to study political texts, Shannon's H (Jennings et al. 2011; Boydstun et al. 2014). Using Shannon's H, we estimate the degree of fractionalization in parties' platforms and then convert this entropy measure into an indicator of the effective number of manifesto issues (ENMI). ${ }^{4}$

\footnotetext{
${ }^{2}$ See appendix for details concerning each outcome variable.

3 The nature of CMP coding means that our measure of issue entrepreneurship captures large innovations, but not subtle breakthroughs within these policy areas (in pay equity, parental leave, and childcare, for example). As discussed below, this biases our findings towards a null result. At the same time, while the categories are broad, the CMPs' common framework makes it the best available data for studying issue entrepreneurship across a wide set of organizations over time.

${ }^{4}$ It is important to note that the measures of both entrepreneurship and scope focus not on "women's issues" in particular, but on the set of issues included in the CMP coding scheme more broadly.
} 
Finally, our third outcome variable focuses on parties' left-right policy positions on a set of common policy dimensions. Following other studies, we use Lowe et al.'s (2011) logit scale to gauge left-right shifts. We opt for this measure because it better accounts for the salience-based nature of the data. With the logit scale, one additional left comment does not have the same effect on the leftright position of a party that has already made a large number of left statements as it does for a party that has not made any left-leaning claims. ${ }^{5}$ We label the left-right position as RILE.

\section{The Explanatory Variable: Operationalizing Diversity}

We posit that diverse parliamentary delegations result in diverse agendas. As a proxy for diversity, the primary explanatory variable is the percentage of seats held by women in the party's parliamentary caucus. ${ }^{6}$ As party platforms are written prior to the election, this variable is lagged. For the 2005 British manifestos, for example, data on the percentage of female MPs in the three major parties is taken from the 2001 general election results. Though information on the total percentage of legislative seats held by women is readily available, no preexisting source reports the gender composition of parties' parliamentary delegations over the full period of our study. Relying primarily on parliamentary websites and archives, we assembled an original dataset on women's inclusion among parties' MPs in 20 democracies. While there is a great deal of variation in women's descriptive representation among the parties in our sample, on average female parliamentarians hold only 20 percent of seats.

\footnotetext{
${ }^{5}$ In robustness checks using the original RILE score, the effect of gender diversity on left-right shifts is not statistically significant.

${ }^{6}$ We undertake a series of analyses using alternate transformations of the primary independent variable, including the squared percentage, a cubic polynomial, and the natural log. The results from these models are consistent with those reported.
} 


\section{Control Variables}

Building on previous studies, we include a number of party- and country-level variables aimed at controlling for omitted variable bias (see appendix for details). At the party-level, we include predictors capturing incumbent status, change in the party's electoral success in the last election (Harmel and Janda 1994), and relative ideological distance from the country-level mean party preference (Lowe et al. 2011). These factors have been shown to affect parties' platforms and may also influence their propensity to select female candidates. We also include an indicator variable denoting whether the party leader is female. Leaders are important actors in manifesto construction, and parties with more female MPs are more likely to be female-led (O’Brien 2015; O’Brien and Rickne Forthcoming). This covariate thus accounts for the possibility of an intervening relationship. ${ }^{7}$ Finally, at the country level we control for majoritarian election rules and the effective number of electoral parties. ${ }^{8}$ This accounts for the possibility that the electoral system shapes both women's descriptive representation and parties' preferences over presenting more or less diverse agendas.

\section{Modeling Strategy}

To examine the relationship between party composition and 1) issue entrepreneurship, 2) issue breadth, and 3) manifestos' left-right location, we fit three models with party-level fixed effects.

\footnotetext{
${ }^{7}$ As a sensitivity analysis, we include a measure of parties' organizational structures similar to Schumacher et al. (2013). Despite our expectations, the findings suggest little effects due to party organization, though future analyses with more dynamic measures may demonstrate clearer results. Analyses controlling for the rise of internet campaigning in the 2000s indicate results similar to those presented in the main models (see appendix for details).

8 We exclude the majoritarian election dummy variable for the issue entrepreneurship model in the main analysis due to its extremely high correlation with the fixed effects.
} 
These models account for idiosyncratic party-level behavior that may influence platform diversity. Model 1 uses binomial logistic regression to predict issue emergence. Model 2 and Model 3 are ordinary least squares regression models predicting ENMI and RILE. All models include a lagged dependent variable to account for autocorrelation. The lagged outcome variable also helps to control for the theoretical expectation that the diversity and ideological location of the previous policy statement may be significant predictors of the form and content of the current manifesto. DickeyFuller tests indicate that panels in most countries are stationary. Sensitivity analyses largely confirm that the results are robust to the time-series specification of the outcome variables. ${ }^{9}$

\section{RESULTS AND DISCUSSION}

As shown in Table 1, the results largely support our theoretical framework. The level of diversity in the parliamentary party clearly shapes parties' election manifestos. Even accounting for a

\footnotetext{
${ }^{9}$ We present the fixed effects models with lagged dependent variables to account for cross-sectional variation and temporal autocorrelation, while allowing us to deal with highly unbalanced panel data in which the number of panels (parties) exceeds the number of time points (elections). Although the structure of the data potentially allows the dependent variable to be autoregressive, Dickey-Fuller tests assure us that at least one panel is stationary in the sample for each dependent variable when a single lag is included and that most countries include at least one stationary series $(95 \%$ confidence or higher). To account for potential issues caused by the few non-stationary series, in the Appendix we present additional time series robustness checks using Mixed Effects, Vector Autoregressive Error Correction, and Equilibrium Response models. We also fit the issue entrepreneurship model using Firth's penalized likelihood approach and the ENMI and RILE models with country- and party-level random effects. The results from these analyses are largely similar to the results presented in the main analysis.
} 
litany of other party- and country-level factors, parties with more female parliamentarians author agendas that are broader in scope and present more left-leaning manifestos. They are not, however, more likely to act as issue entrepreneurs.

\section{INSERT TABLE 1 HERE}

Our first hypothesis (H1) predicts that parties with more female parliamentarians will be more likely to include new topics on their manifestos. The coefficient estimate for the covariate capturing the percentage of female MPs in Model 1, however, is non-significant. Parties in which women hold more seats are no more likely to include new issues on their platforms than those with less diversity among their parliamentary delegates. This suggests that diversity does not necessarily lead parties to innovate in broad topic areas that have not previously been politicized in the country. While women may highlight new issues within these arenas-such as childcare provisions and maternity leave under the umbrella of welfare state expansion-in the aggregate their presence is not associated with large-scale entrepreneurship. At the same time, it is worth noting that none of the well-established variables explaining party behavior predict issue emergence. Future work is needed to understand both the circumstances in which diversity leads to issue entrepreneurship within policy subcategories, as well as to identify the mechanisms driving this phenomenon more generally.

Our second hypothesis (H2) posits that parties with more women in their parliamentary delegations will be more likely to include a greater set of issues on their election manifestos. Unlike before, we find strong support for this claim. The coefficient estimate for the percentage of female MPs in Model 2 is positive and significant (at the $\alpha=0.05$ level). When the proportion of seats held by female MPs is larger, parties increase the diversity of issues referenced on their manifestos. We demonstrate this relationship in Figure 1, which plots predicted ENMI values against women's descriptive representation. Comparing one standard deviation below and above the mean level of gender diversity increases the ENMI measure by 1.27 (95\% CI: 0.47, 2.07). This is an increase of 
approximately $4.4 \%$ over the range of ENMI, a change that corresponds to the inclusion of nearly one full additional topic on the party manifesto (holding all other variables constant).

\section{INSERT FIGURE 1 HERE}

The results in Model 3 support our third hypothesis. We theorized that greater diversity has both direct and indirect effects on parties' ideological stances. In particular, the more women in the parliamentary delegation, the more likely a party should be to shift its position leftwards. That is, women's descriptive representation is expected to be negatively correlated with the party's RILE score. As posited, even when controlling for the party's previous ideological position, the coefficient for the percentage of female MPs is negative and significant (at the $\alpha=0.01$ level). Figure 2 demonstrates the effect of gender diversity on parties' RILE scores. Moving from one standard deviation below to one above the mean level of gender diversity leads to a -0.20 change on this leftright measure (95\% CI: $-0.28,-0.13)$. This corresponds to a 5 percent decrease over the range of the RILE score.

\section{INSERT FIGURE 2 HERE}

Finally, our results are even more striking when viewed alongside our control variables. The models in Table 1 suggest that the presence of a female leader results in a more diverse agenda, though the effect size is smaller than the coefficient capturing women's presence in the parliamentary delegation. Female leaders have no effect, moreover, on parties' left-right positions. The selection of a new type of leader may thus facilitate the inclusion of new ideas, but is unlikely to generate fundamental shifts in parties' ideological locations.

Majoritarian systems likewise increase ENMI and are also associated with more left-leaning manifestos than proportional systems. By encouraging candidate-centered appeals (e.g. Carey and Shugart 1995), these electoral rules incentivize parties to include more issues on their manifestos. Incumbent parties are also slightly more leftward than opposition parties, all else equal. When in 
government, parties are often forced to respond to policy change on a range of issues in order to avoid appearing irresponsible or unaccountable. Often these issues require more active government support, and defending these actions within the manifesto leads to leftward shifts. The remaining control variables have no effect on issue entrepreneurship, platform scope, or the left-right position of the manifesto. Accounting for other factors and party-level fixed effects, change in vote-share, ideological distance, and the effective number of parties fail to predict any of our three outcome variables. Indeed, the proportion of female MPs better explains the diversity of parties' policy statements than these key characteristics.

We have theorized and demonstrated a new way in which the inclusion of group representatives matters for policy formation. Just as female MPs sometimes hold distinct preferences and priorities, their presence also leads parties to advance more topically diverse agendas. While existing work often focuses on the link between descriptive and substantive representation, our findings indicate that integrating women's viewpoints has broader effects on parties' manifestos. Irrespective of whether women's presence results in the adoption of policy explicitly related to women, it likely has wider-and previously overlooked-consequences for the policymaking process.

These results, in turn, have important implications for research on agenda formation and the study of the effects of descriptive representation. While previous work on party manifestos overlooked the makeup of the parliamentary delegation, we show that MPs' characteristics help explain changes in party policy, including the left-right location of the platform and its scope. By focusing on diversity generally, and women's representation in particular, we offer a framework for understanding when and why the parliamentary delegation influences manifesto formation. 


\section{CONCLUSIONS}

This paper integrates the parliamentary delegation into the agenda formation process. We argue that the makeup of the parliamentary caucus influences the election manifesto, particularly when parliamentarians hold distinctive viewpoints and give voice to these perspectives. Consequently, we posited that parties with more diverse delegations are likely to campaign on new issues, emphasize a broader range of topics on their electoral platforms, and even adjust their leftright positions.

Using women's representation as a measure of diversity, we conducted the most comprehensive party-level study of women's representation to date, examining 899 party manifestos from 20 countries in elections held between 1952 and 2011. Although our sample represents a difficult test for our theory, the results from our analysis support two of our three hypotheses. As the percentage of female MPs increases, parties address a wider scope of issues in their election campaigns. Women's presence is also associated with more left-leaning manifestos, even when controlling for parties' prior ideological positions. While we do not find support for our issue entrepreneurship hypothesis, moreover, we believe that this remains a promising area for future research. Altogether, our results suggest that women's descriptive representation in parties' delegations shifts parties' policy statements. These findings have important implications for studies of party politics, as well as for empirical and normative research on descriptive representation.

For party scholars, our work helps to unpack the black box of intra-party politics and sheds new light on the policymaking process. To date, it has been difficult to develop and test clear expectations concerning why (and in what ways) intra-party variation is likely to impact parties' manifestos. We demonstrate that (lack of) diversity among elected representatives is likely to have broad consequences for campaign messages. While this analysis focuses on women's representation, we expect that this relationship holds for other traditionally underrepresented groups, as well as for 
interests that are not based on ascriptive identity. That is, we believe that the scope and content of issues presented to the public, and thus the very nature of representative claims, often depend on the makeup of the parliamentary delegation. Future work should not overlook this important explanatory factor when studying party agenda construction and change.

These findings hold similar importance for those interested in the broader implications of descriptive representation. We show that bolstering diversity within the parliamentary party has implications for the policy agenda beyond increasing attention to historically marginalized groups. While a large body of work examines whether female MPs place "women's issues" on the agenda, we find that they broaden the scope of the platform and generate more attention to leftist issues. These results lend support to a key-but as of yet largely untested-assumption underpinning normative arguments in favor of women's representation. Importantly, they also suggest that the exclusion of historically marginalized groups not only inhibits the substantive representation of group interests, but may also result in parties presenting narrower platforms to the public. By broadening the party's focus, diversity arguably improves the quality of representation for all citizens. 


\section{REFERENCES}

Adams, James, Michael Clark, Lawrence Ezrow, and Garrett Glasgow. 2006. "Are Niche Parties Fundamentally Different from Mainstream Parties? The Causes and the Electoral Consequences of Western European Parties’ Policy Shifts, 1976-1998.” American Journal of Political Science 50(3):513-29.

Adams, James, and Lawrence Ezrow. 2009. "Who Do European Parties Represent? How Western European Parties Represent the Policy Preferences of Opinion Leaders.” The Journal of Politics 71(01):206-23.

Adams, James, Andrea B. Haupt, and Heather Stoll. 2009. "What Moves Parties? The Role of Public Opinion and Global Economic Conditions in Western Europe.” Comparative Political Studies 42(5):611-39.

Adams, James, and Zeynep Somer-Topcu. 2009. "Policy Adjustment by Parties in Response to Rival Parties’ Policy Shifts: Spatial Theory and the Dynamics of Party Competition in Twenty-Five Post-War Democracies.” British Journal of Political Science 39(4):825-46.

Annesley, Claire, Isabelle Engeli, and Franesca Gains. Forthcoming. "The Profile of Gender Equality Issue Attention in Western Europe." European Journal of Political Research.

Bäck, Hanna, Marc Debus, and Patrick Dumont. 2011. "Who Gets What in Coalition Governments? Predictors of Portfolio Allocation in Parliamentary Democracies.” European Journal of Political Research 50(4):441-78.

Barnes, Tiffany D. 2016. Gendering Legislative Behavior: Institutional Constraints and Collaboration. New York: Cambridge University Press.

Bawn, Kathleen, and Zeynep Somer-Topcu. 2012. "Government versus Opposition at the Polls: How Governing Status Affects the Impact of Policy Positions.” American Journal of Political Science 56(2):433-46. 
Bernauer, Julian, and Thomas Bräuninger. 2009. "Intra-Party Preference Heterogeneity and Faction Membership in the 15th German Bundestag: A Computational Text Analysis of Parliamentary Speeches." German Politics 18(3):385-402.

Best, Robin E. 2011. “The Declining Electoral Relevance of Traditional Cleavage Groups.” European Political Science Review 3(02):279-300.

Bochel, Catherine, and Hugh Bochel. 2008. "Women 'leaders' in local government in the UK." Parliamentary Affairs 61(3): 426-441.

Boydstun, Amber E., Davis Shaun Bevan, and Herschel F. Thomas. 2014. "The Importance of Attention Diversity and How to Measure It.” Policy Studies Journal.

Budge, Ian, Hans Dieter Klingemann, Andrea Volkens, Judith Bara and Eric Tanenbaum. 2001. Mapping Policy Preferences, Estimates for Parties, Governments and Electors 1945-1998. Oxford: Oxford University Press.

Carey, John M., and Matthew Soberg Shugart. 1995. "Incentives to cultivate a personal vote: a rank ordering of electoral formulas." Electoral Studies 14(4): 417-439.

Carmines, Edward G., and James A. Stimson. 1989. Issue Evolution: Race and the Transformation of American Politics. Princeton: Princeton University Press.

Ceron, Andrea. 2012. "Bounded Oligarchy: How and When Factions Constrain Leaders in Party Position-Taking.” Electoral Studies 31(4):689-701.

Ceron, Andrea. 2013. "Brave Rebels Stay Home: Assessing the Effect of Intra-Party Ideological Heterogeneity and Party Whip on Roll-Call Votes." Party Politics.

Childs, Sarah, and Paul Webb. 2012. Sex, Gender and the Conservative Party: From Iron Lady to Kitten Heels. Palgrave Macmillan. 
Debus, Marc, and Thomas Bräuninger. 2008. "Intra-Party Factions and Coalition Bargaining in Germany." In Intra-Party Politics and Coalition Governance, by Daniela Gianetti and Kenneth Benoit, eds. Routledge. 121-45.

De Vries, Catherine E., and Sara B. Hobolt. 2012. "When Dimensions Collide: The Electoral Success of Issue Entrepreneurs.” European Union Politics 13(2):246-68.

Diaz, Mercedes Mateo. 2005. Representing Women?:Female Legislators in West European Parliaments. Colchester: ECPR Press.

Downs, Anthony. 1957. An Economic Theory of Democracy. New York: Harper and Row.

Egan, Patrick J. 2013. Partisan Priorities: How Issue Ownership Drives and Distorts American Politics. New York: Cambridge University Press.

Esaiasson, Peter, and Sören Holmberg. 1996. Representation from Above: Members of Parliament and Representative Democracy in Sweden. Aldershot: Dartmouth Publishing Company.

Esaiasson, Peter. "How Members of Parliament Define Their Task." 2000. In From Westminster to Congress and Beyond. The Nordic Experience, by Knut Heidar, ed. Columbus: Ohio State University Press, 51-82.

Erzeel, Silvia. 2015. "Explaining Legislators' Acting on Behalf of Women in the Parliamentary Party Group: The Role of Attitudes, Resources and Opportunities." Journal of Women, Politics \& Policy 36(4):440-463.

Ezrow, Lawrence. 2007. "The Variance Matters: How Party Systems Represent the Preferences of Voters." Journal of Politics 69(1):182-92.

Ezrow, Lawrence. 2008. 'Parties' Policy Programmes and the Dog That Didn’t Bark: No Evidence That Proportional Systems Promote Extreme Party Positioning." British Journal of Political Science 38(3):479. 
Ezrow, Lawrence, Catherine De Vries, Marco Steenbergen, and Erica Edwards. 2011. "Mean Voter Representation and Partisan Constituency Representation: Do Parties Respond to the Mean Voter Position or to Their Supporters?” Party Politics 17(3):275-301.

Franceschet, Susan, and Jennifer M. Piscopo. 2008. Gender Quotas and Women's Substantive Representation: Lessons from Argentina. Politics \& Gender, 4(3):393-425.

Giannetti, Daniela, and Kenneth Benoit. 2008. Intra-Party Politics and Coalition Governments. New York:Routledge.

Green, Jane, and Will Jennings. 2012. “The Dynamics of Issue Competence and Vote for Parties in and out of Power: An Analysis of Valence in Britain, 1979-1997." European Journal of Political Research 51(4):469-503.

Greene, Zachary, and Matthias Haber. 2014. "Leadership Competition and Disagreement at Party National Congresses.” British Journal of Political Science FirstView: 1-22.

Greene, Zachary, and Christian Jensen. 2014. "Manifestos, Salience and Junior Ministerial Appointments.” Party Politics OnlineFirst: 1-11.

Greene, Zachary. 2015. "Competing on the Issues: How Experience in Government and Economic Conditions Influence the Scope of Parties’ Policy Messages.” Party Politics OnlineFirst: 1-14.

Harmel, Robert, and Kenneth Janda. 1994. "An Integrated Theory of Party Goals and Party Change." Journal of Theoretical Politics 6(3):259-87.

Hellwig, Timothy. 2012. "Constructing Accountability Party Position Taking and Economic Voting." Comparative Political Studies 45(1):91-118.

Hibbs Jr, Douglas A. 1977. "Political Parties and Macroeconomic Policy." American Political Science Review 71(4):1467-87.

Jennings, Will, Shaun Bevan, Arco Timmermans, Gerard Breeman, Sylvain Brouard, Laura ChaquésBonafont, Christoffer Green-Pederson, Peter John, Peter Mortensen and Anna M. Palau. 
2011. "Effects of the Core Functions of Government on the Diversity of Executive Agendas." Comparative Political Studies 44:1001-1030.

Jones, Mark P. 1997. "Legislator Gender and Legislator Policy Priorities in the Argentine Chamber of Deputies and the United States House of Representatives.” Policy Studies Journal 25(4):613_ 29.

Kittilson, Miki Caul. 2008. "Representing Women: The Adoption of Family Leave in Comparative Perspective." Journal of Politics 70(02):323-34.

Kittilson, Miki Caul. 2010. "Women, Parties and Platforms in Post-Industrial Democracies." Party Politics 17(1):66-92.

Klingemann, Hans-Dieter, Andrea Volkens, Judith Bara, Ian Budge, and Michael McDonald. 2006. Mapping Policy Preferences II: Estimates for Parties, Electors, and Governments in Eastern Europe, European Union and OECD 1990- 2003. Oxford: Oxford University Press.

Klüver, Heike, and Jae-Jae Spoon. Forthcoming. "Who Responds? Voters, Parties and Issue Attention." British Journal of Political Science.

Laver, Michael. 1999. “Divided Parties, Divided Government.” Legislative Studies Quarterly 24(1):5-29.

Laver, Michael, and Kenneth A. Shepsle. 1996. Making and Breaking Governments: Cabinets and Legislatures in Parliamentary Democracies. Cambridge: Cambridge University Press.

Lehrer, Ron. 2012. "Intra-Party Democracy and Party Responsiveness." West European Politics 35(6):1295-1319.

Lovenduski, Joni and Pippa Norris. 2003. "Westminster Women: The Politics of Presence.” Political Studies 51(1):84-102.

Lowe, Will, Kenneth Benoit, Slava Mikhaylov, and Michael Laver. 2011. "Scaling Policy Preferences from Coded Political Texts.” Legislative Studies Quarterly 36(1):123-55. 
Mansbridge, Jane. 1999. "Should Blacks Represent Blacks and Women Represent Women? A Contingent 'yes." Journal of Politics 61(03):628-57.

McAllister, Ian, and Donley T. Studlar. 1992. “Gender and Representation among Legislative Candidates in Australia." Comparative Political Studies 25(3):388-411.

McElwain, Kenneth Mori. 2008. "Manipulating Electoral Rules to Manufacture Single-Party Dominance." American Journal of Political Science 52(1):32-47.

Meguid, Bonnie M. 2008. Party Competition between Unequals: Strategies and Electoral Fortunes in Western Europe. Cambridge: Cambridge University Press.

Narud, Hanne Marthe, and Henry Valen. 2000. “Does Social Background Matter?” In Beyond Westminster and Congress, by Peter Esaiasson and Knut Heidar, eds. Columbus: Ohio State University Press, 83-106.

Norris, Pippa. 1996. "Women Politicians: Transforming Westminster?” Parliamentary Affairs 49(1):89-102.

Norton, Philip. 1999. “The Individual Member in the British House of Commons: Facing Both Ways and Marching Forward.” The Journal of Legislative Studies 5(3-4):53-74.

O’Brien, Diana Z. 2015. "Rising to the Top: Gender, Political Performance, and Party Leadership in Advanced Industrial Democracies." American Journal of Political Science 59(4): 1022-1039.

O’Brien, Diana Z. and Johanna Rickne. Forthcoming. “Gender Quotas and Women's Access to Leadership Posts." American Political Science Review.

Patzelt, Werner J. 1997. “German MPs and Their Roles.” The Journal of Legislative Studies 3(1):55-78.

Patzelt, Werner J. 1999. "What Can an Individual MP Do in German Parliamentary Politics?” The Journal of Legislative Studies 5(3-4):23-52.

Petrocik, John R. 1996. "Issue Ownership in Presidential Elections, with a 1980 Case Study." American Journal of Political Science 40(3):825-50. 
Phillips, Anne. 1995. The Politics of Presence. Oxford: Oxford University Press.

Schumacher, Gijs, Catherine E. de Vries, and Barbara Vis. 2013. "Why Do Parties Change Position? Party Organization and Environmental Incentives.” The Journal of Politics 75(02):464-77.

Searing, Donald. 1994. Westminster's World: Understanding Political Roles. Cambridge: Cambridge University Press.

Somer-Topcu, Zeynep. 2009. “Timely Decisions: The Effects of Past National Elections on Party Policy Change." The Journal of Politics 71(01):238-48.

Spoon, Jae-Jae. 2011. Political Survival of Small Parties in Europe. Ann Arbor: University of Michigan Spoon, Jae-Jae, and Heike Klüver. 2014. "Do parties respond? How electoral context influences party responsiveness." Electoral Studies 35: 48-60.

Spoon, Jae-Jae, Sara B. Hobolt, and Catherine E. Vries. 2013. "Going Green: Explaining Issue Competition on the Environment." European Journal of Political Research.

Stoll, Heather. 2010. "Elite-Level Conflict Salience and Dimensionality in Western Europe: Concepts and Empirical Findings." West European Politics, 33(3):445-473.

Tavits, Margit. 2007. "Principle vs. Pragmatism: Policy Shifts and Political Competition.” American Journal of Political Science 51(1):151-65.

Thomassen, Jacques, and Rudy B. Andeweg. 2004. "Beyond Collective Representation: Individual Members of Parliament and Interest Representation in the Netherlands." The Journal of Legislative Studies 10(4):47-69.

Thomson, Robert. 2001. “The Programme to Policy Linkage: The Fulfillment of Election Pledges on Socio-Economic Policy in the Netherlands, 1986-1998." European Journal of Political Research 40(2):171-97.

Thomson, Robert, Terry Royed, Elin Naurin, Joaquin Artes, Mark Ferguson, Petia Kostadinova and Catherine Moury. 2012. “The Program-to-Policy Linkage: A Comparative Study of Election 
Pledges and Government Policies in Ten Countries.” Presented at the 2012 Annual Meeting of the American Political Science Association.

Volkens, Andrea; Lacewell, Onawa; Lehmann, Pola; Regel, Sven; Schultze, Henrike; Werner, Annika. 2011. The Manifesto Data Collection. Manifesto Project (MRG/CMP/MARPOR). Berlin:Wissen- schaftszentrum Berlin für Sozialforschung (WZB).

Wagner, Markus, and Thomas M. Meyer. 2014. 'Which Issues Do Parties Emphasise? Salience Strategies and Party Organisation in Multiparty Systems.” West European Politics 37(5):1019_ 45.

Wängnerud, Lena. 2000. “Testing the Politics of Presence: Women’s Representation in the Swedish Riksdag.” Scandinavian Political Studies 23(1):67-91.

Williams, Laron K., Katsunori Seki, and Guy D. Whitten. 2014."You've Got Some Explaining To Do:The Influence of Economic Conditions and Spatial Competition on Party Strategy.” Political Science and Research Methods (forthcoming).

Williams, Melissa S. 2000. Voice, Trust, and Memory: Marginalized Groups and the Failings of Liberal Representation. Princeton: Princeton University Press.

Wiliarty, Sarah. 2010. The CDU and the Politics of Gender in Germany: Bringing Women to the Party. New York: Cambridge University Press.

Xydias, Christina V. 2007. “Inviting More Women to the Party: Gender Quotas and Women's Substantive Representation in Germany." International Journal of Sociology 37(4):52-66.

Xydias, Christina. 2013. "Mapping the Language of Women's Interests: Sex and Party Affiliation in the Bundestag." Political Studies 61(2):319-340.

Young, Iris Marion. 2002. Inclusion and Democracy. Oxford: Oxford University Press. 


\title{
Diverse Parties, Diverse Agendas? Female Politicians and the Parliamentary Party's Role in Platform Formation
}

\begin{abstract}
APPENDIX
In this Appendix, we offer additional information in support of the main arguments presented in the text. In particular, we present the measurement of one of the key dependent variables (ENMI), as well as the descriptive statistics for the primary variables. Furthermore, we present the results from a number of statistical robustness checks that provide supplementary evidence for our theory linking diverse parties and diverse agendas.
\end{abstract}

\section{MEASURING ENMI}

Following Jost (2006) and Greene (2015) ${ }^{1}$ we use the formula below to construct the ENMI (effective number of manifesto issues) measure. In equation (1), $m_{i}$ represents the percentage of the manifesto — as measured by the Comparative Manifestos Project (CMP)—dedicated to issue $i$ for each of the 42 issue categories ${ }^{2}$ used by the CMP coders. ${ }^{3}$ We exponentiate Shannon's $H$ to transform the variable from a measure of entropy to a measure of diversity. Mathematical diversity is thus a characteristic of a set of groups that summarizes both the number of categories (policy areas) and the relative distribution of the population (manifesto quasi-sentences) across those categories.

In equation (3), we provide an example of our measure in action. For a hypothetical manifesto with only two quasi-sentences addressing two separate issues-that is, $50 \%$ of overall attention to each issue area-ENMI equals 2. If the party added a third sentence addressing an additional topic, ENMI would increase to $3 .{ }^{4} \mathrm{~A}$ theoretical party distributing its issue attention (quasisentences) equally across all 42 categories would have the maximum possible ENMI of 42.

\footnotetext{
${ }^{1}$ Nyblade (2004) and Stoll (2011) perform a similar modification to the Herfindahl index to arrive at their measures of the effective number of issues. The Herfindahl index, however, is biased towards the most dominant categories. In this way, it is an indicator of the largest categories' relative dominance rather than a "true" measure of entropy like Shannon's H (Shannon 1948; Jost 2006).

${ }^{2}$ Following Lowe et al. (2011), we collapse the natural confrontational pairs contained in the CMP so that we avoid over-counting any of these distinct topics. In particular, we combine categories on 1) "Foreign Special Relationships: positive" and "Foreign Special Relationships: negative"; 2) "Military: positive" and "Military: negative"; 3) "Internationalism: positive" and "Internationalism: negative"; 4) "European Community: positive" and "European Community: negative"; 5) "Constitutionalism: positive" and "Constitutionalism: negative"; 6) "Decentralisation" and "Centralisation"; 7) "Protectionism: Positive" and "Protectionism: negative"; 8) "Welfare State Expansion" and "Welfare State Limitation"; 9) "Education Expansion" and "Education Limitation"; 10) "National Way of Life: positive" and "National Way of Life: negative"; 11) "Traditional Morality: positive" and "Traditional Morality: negative"; 12) "Multiculturalism: positive" and "Multiculturalism: negative"; 13 "Labour Groups: positive" and "Labour Groups: negative"; and lastly 14) "Keynesian Demand Management: Positive" and "Economic Orthodoxy: Positive." By collapsing these categories we decrease the total number of possible issue topics from 56 to 42.

${ }^{3}$ Following Jennings et al. (2011), we replace $\ln (0)$ with zero.

${ }^{4}$ Note that our measure arrives at identical scores as Laakso and Taagepera's (1979) formula when the distribution of issues is equal in each category. Otherwise, their measure tends to
} 


$$
\text { Shannon's } H=-\sum_{i=1}^{42} m_{i} \ln \left(m_{i}\right)
$$

$$
E N M I=\exp (\text { Shannon's } H)^{\prime}
$$

$$
\begin{gathered}
2=\exp \left(-\left(\left(.5_{1}\right) \ln \left(.5_{1}\right)\right)+\left(\left(.5_{2}\right) \ln \left(.5_{2}\right)\right) \ldots\right. \\
\left.+\left(\left(0_{42}\right) \ln \left(0_{42}\right)\right)\right)
\end{gathered}
$$

\section{VARIABLE DESCRIPTIONS}

Table 1 provides descriptions of the outcome and explanatory variables.

Table 1. Descriptive Statistics

\begin{tabular}{lccccc}
\hline & Mean & S.D. & Min & Max & N \\
\hline Iss. Entrep. & 0.0423 & 0.201 & 0 & 1 & 899 \\
ENMI & 16.78 & 5.579 & 1 & 29.82 & 899 \\
RILE & -0.548 & 0.604 & -2.753 & 1.309 & 892 \\
\% Female MPs & 0.194 & 0.163 & 0 & 1 & 899 \\
Female Leader & 0.115 & 0.319 & 0 & 1 & 899 \\
Incumbent & 0.400 & 0.490 & 0 & 1 & 899 \\
Ideol. Distancet-1 $_{\text {\% Votet-1 }}$ & 0.329 & 0.269 & 0.00108 & 1.632 & 899 \\
Majoritarian $_{\text {ENEP }}$ - & 21.06 & 15.08 & 0.280 & 57.71 & 899 \\
Federalism & 0.189 & 0.392 & 0 & 1 & 899 \\
\hline
\end{tabular}

Table 1 highlights differences amongst the three dependent variables. In particular, the sample includes substantial variation in ENMI and RILE scores, though few examples of issue entrepreneurship. On the whole, like other studies of party policy change, we believe these measures provide important information about the dynamics of election campaigns and future policy change (e.g. de Vries and Hobolt 2012; Greene 2015; Lowe et al. 2011).

In contrast to the variation in ENMI and RILE scores, examples of issue entrepreneurship are less common. Parties rarely act as issue entrepreneurs in the sample, reflecting the conservative nature of our measure. An issue can only be included as a novel contribution in a country the first time it is discussed. This limits the total hypothetical number of issue emergence

indicate slightly less diversity (smaller numbers) as the Herfindahl index over counts the size of the largest categories (Jost 2006). 
opportunities for any country to 42 (the total number of issue categories used once explicitly directional issues are collapsed). Parties thus only act as entrepreneurs in $4.2 \%$ of cases.

The relatively broad issue categories included in the CMP also limits the extent to which innovation can be identified using this data. From a substantive standpoint, this measure cannot capture nuanced differences in the discussion of specific policies, such as childcare and maternity leave, as both are captured by Issue Code 504-"Welfare State Expansion." Indeed, this is not a new problem, as Kittilson (2010) discusses the broad nature of the CMP's policy codes. As she concludes, however, the CMP provides the most comprehensive indicator of issue salience at the party level available for a wide range of advanced democracies over time.

Unlike issue entrepreneurship, Table 1 shows significant variation in ENMI. While increased attention to issues such as childcare and maternity leave is unlikely to register as issue emergence, moreover, it would likely affect this policy scope measure. Overall, parties with no female MPs have an ENMI of 15 on average while parties with any female MPs increase to 16.7. Focusing on welfare policies (codes 504 and 505) in particular, parties with any women in their parliamentary delegations dedicate $1.5 \%$ more attention to the welfare state than those without female MPs. More broadly, ENMI has increased over time in most countries. This reflects the addition of new, post-materialist issues-like environmental concerns - to the policy agenda. Consistent with Greene (2015), niche parties (e.g. green parties) include fewer issues (13.1) on average than mainstream social democratic (16.9) and conservative (16.5) parties. For additional discussion of ENMI's validity see Nyblade (2004) and Greene (2015). Stoll (2010) likewise provides a measure of ideological dimensionality based on similar principles.

Finally, the measure of left-right preferences in the CMP has seen substantial use in the study of party positions (e.g. Adams et al. 2006; Adams and Somer-Topcu 2009; de Vries and Hobolt 2012; Ezrow 2008; Meguid 2008; Wagner 2012). Lowe et al.'s (2011) logged scale accounts for the diminishing effect of statements on the party's left-right position, although it means that there is no natural center position. On average, social democratic parties (-.74) are more left leaning (negative) than conservative parties (-.23). In general, the left-right scale provides us with a reasonable indicator of parties' relative positions on a broad economic policy dimension.

\section{ROBUSTNESS CHECKS}

In the article, we note the possibility of potential confounding factors due to the cross-sectional time series structure of the data. Although Dickey-Fuller tests indicate that most countries include stationary panels, non-stationary processes in some panels may generate biased results. We account for these processes using two alternate techniques that transform the data into stationary processes: Error Correction Models and Equilibrium Response Models. The results from these analyses are largely consistent with those in the main text and provide interesting information about the relationship between the primary independent variable and party platform change.

\section{Error Correction and Event History Models}

In Table A1, we present the results of an error correction model for ENMI and RILE. We also estimate an event history model of issue entrepreneurship with clustered standard errors on party. ${ }^{5}$ We treat issue entrepreneurship as a discrete event history model where we include a

\footnotetext{
${ }^{5}$ The results in Model A1 include a linear trend, which is positive and significant (at the $\alpha=0.05$ level). Alternative specifications that include other transformations of time since the last
} 
count for the number of elections since the last time the party acted as an entrepreneur. By fitting error correction models ${ }^{6}$ and an event history model for issue entrepreneurship, we decrease the risk of autocorrelation driving the results by producing stationary series.

The results in Table A1 provide evidence that parallels the results presented in the main text. In Model A1, we predict whether long- or short-term levels of gender diversity influence the likelihood of acting as an issue entrepreneur. The coefficients for both variables are negative, in contrast to the prediction from the first hypothesis. There is little evidence that the percentage of female MPs influences parties' propensity to introduce a brand new issue that has never before been discussed in the state.

Model A2 in Table A1 demonstrates evidence in support of the second hypothesis. The coefficients for both the long- and short-term effects are both positive and the short-term effect is statistically different from zero at the $\alpha=0.1$ level. The short term effect is also substantively meaningful. Controlling for all other covariates, parties in which women increase their seat share by $10 \%$ increase their ENMI by 0.3 as compared to parties that maintain a stable percentage of female MPs. Gender diversity thus has a short-term effect on the scope of parties' policy statements.

Table A1 also provides support for the third hypothesis. Parties with greater diversity in their parliamentary caucuses are further to the left than their less diverse counterparts. The coefficients for both variables capturing women's descriptive representation are negative and statistically significant. Consistent with our theoretical approach, this suggests that increasing gender diversity leads parties to move to the left both in the short- and long-term.

\section{Equilibrium Response Models}

An alternate approach based on McDonald and Best (2006) involves directly estimating each panel's equilibrium level of the dependent variable. Here, as an explanatory variable the model includes the panel's sample mean value of the dependent variable. This accounts for the equilibrium reversion value of this dependent variable. To account for past changes to the equilibrium level, the model also includes a measure of the equilibrium variable minus the lagged value of the dependent variable $(t-1)$. Here, the equilibrium variable should be equal to one. The lagged difference captures the speed with which deviations return to equilibrium values.

We present the results from this approach in Table A2. These findings are broadly consistent with the previous analysis. In particular, we find additional support for the second hypothesis. As the lagged percentage of female MPs increases, ENMI also increases. The coefficient is large and statistically significant at the $\alpha=0.1$ level. A $10 \%$ increase in female MP diversity is associated to a 0.23 increase in ENMI. The coefficient for the equilibrium and lagged dependent variable further suggest that the magnitude of this change would take multiple elections to return to equilibrium.

The evidence for the third hypothesis in Table A2 is also strong. The coefficient for gender diversity is negative and statistically different from zero. These results should be cautiously interpreted on their own, however, as McDonald and Best (2006) indicate that a coefficient value

entrepreneurship event - including logged, inverted, exponentiated, and cubic polynomials-lead to nearly identical results with respect to both substantive magnitude and statistical significance. ${ }^{6}$ Error correction models include panel corrected standard errors accounting for panel specific AR1 processes. 
overly large or small (i.e. not equal to 1) for the equilibrium variable suggests that the equilibrium model does not perform particularly well.

Together these results are broadly consistent with our findings. Although we found limited evidence of non-stationarity in most panels, the results from models accounting for autoregressive tendencies largely corroborate of our theory of diversity and platform formation.

\section{Firth's Penalized Likelihood Approach}

Issue entrepreneurship can be considered a rare event, with only 34 instances in the dataset. Consequently, we estimated the model using Firth's penalized likelihood approach, a common strategy for dealing with rare events (Table A3). As before, the relationship between entrepreneurship and the proportion of female MPs remains non-significant.

\section{Random Effects Models}

The paper presents the results from our fixed effects models. In order to account for the covariance between parties across elections and within a given country, the data was also analyzed using varying-intercepts random effects models (Table A4). We use country- and partylevel grouping variables, such that the hierarchical structure of our data consists of partyelections nested within 110 parties and 20 countries. The results are consistent with the findings presented in the paper, although the variable drops just below significance in the issue diversity model.

\section{Party organization}

Parties' organizational structure plays an important role in their decision-making (e.g. Schumacher et al. 2013). Although our theoretical mechanism suggests that MP diversity directs party policy change due to credible suggest new ideas and slight differences in their policy interests, the degree to which party leaders dominate the manifesto writing process might also matter. To account for this argument, we include a variable to account for the party's organizational hierarchy similar to Schumacher et al. (2013) based on expert evaluations of parties' organizations. ${ }^{7}$ Despite its limiting our sample substantially in terms of country and party scope, the inclusion of this variable in Table A5 provides additional evidence for our theory.

\section{Web 2.0}

Changing means of campaign communications likely has had real implications for parties' policy messages. Studies of electronic media suggest that they largely reflect similar substance as more traditional campaign media (Gibson 2012), but the usage of online social media might also have an effect on issue diversity and policy positions. To account for this potential we run the analysis including a dummy variable to account for the emergence of campaigning in the Web 2.0 era that equals 1 for all elections starting in 2000. Table A6 indicates that the inclusion of this control variable leads to substantively similar results to those presented in the main analysis.

\footnotetext{
${ }^{7}$ The constitutive term is dropped from the models due to the inclusion of fixed effects and the lack of variance in the leadership control variable.
} 
Table A1. Event History and Error Correction Models

\begin{tabular}{|c|c|c|c|}
\hline & $\begin{array}{c}\text { (1) } \\
\text { Issue Entrep. }\end{array}$ & $\begin{array}{c}(2) \\
\text { ENMI }\end{array}$ & $\begin{array}{c}\text { (3) } \\
\text { RILE }\end{array}$ \\
\hline \multicolumn{4}{|l|}{ main } \\
\hline$\Delta \%$ Female MPs & $\begin{array}{l}-0.195 \\
(1.002)\end{array}$ & $\begin{array}{l}2.903^{+} \\
(1.582)\end{array}$ & $\begin{array}{c}-0.390^{* *} \\
(0.133)\end{array}$ \\
\hline$\%$ Female MPS $\mathrm{s}_{\mathrm{t}-1}$ & $\begin{array}{l}-0.160 \\
(0.646)\end{array}$ & $\begin{array}{c}0.358 \\
(1.155)\end{array}$ & $\begin{array}{l}-0.182^{+} \\
(0.094)\end{array}$ \\
\hline$\Delta \%$ Female Leader & $\begin{array}{l}-0.161 \\
(0.399)\end{array}$ & $\begin{array}{c}0.708 \\
(0.501)\end{array}$ & $\begin{array}{c}0.039 \\
(0.049)\end{array}$ \\
\hline Female Leader $r_{t-1}$ & $\begin{array}{l}-0.125 \\
(0.295)\end{array}$ & $\begin{array}{c}0.228 \\
(0.438)\end{array}$ & $\begin{array}{l}-0.076 \\
(0.053)\end{array}$ \\
\hline$\Delta$ Incumbent Party $\mathrm{t}-1$ & $\begin{array}{l}-0.222 \\
(0.169)\end{array}$ & $\begin{array}{c}0.077 \\
(0.297)\end{array}$ & $\begin{array}{l}-0.037 \\
(0.029)\end{array}$ \\
\hline Incumbent $_{\mathrm{t}-1}$ & $\begin{array}{c}0.225 \\
(0.243)\end{array}$ & $\begin{array}{l}-0.458 \\
(0.365)\end{array}$ & $\begin{array}{c}0.016 \\
(0.036)\end{array}$ \\
\hline$\Delta$ Ideol. Distance $_{\mathrm{t}-1}$ & $\begin{array}{l}-0.222 \\
(0.372)\end{array}$ & $\begin{array}{c}0.507 \\
(0.615)\end{array}$ & $\begin{array}{c}0.053 \\
(0.060)\end{array}$ \\
\hline Ideol. Distance $_{\mathrm{t}-2}$ & $\begin{array}{l}-0.356 \\
(0.460)\end{array}$ & $\begin{array}{c}1.139 \\
(0.745)\end{array}$ & $\begin{array}{c}0.063 \\
(0.057)\end{array}$ \\
\hline$\Delta \%$ Vote & $\begin{array}{c}0.003 \\
(0.016)\end{array}$ & $\begin{array}{c}0.048 \\
(0.031)\end{array}$ & $\begin{array}{l}-0.007^{*} \\
(0.003)\end{array}$ \\
\hline$\%$ Votet $-1_{1}$ & $\begin{array}{c}0.005 \\
(0.009)\end{array}$ & $\begin{array}{l}0.033^{*} \\
(0.013)\end{array}$ & $\begin{array}{l}-0.002 \\
(0.001)\end{array}$ \\
\hline Majoritarian & $\begin{array}{c}0.273 \\
(0.211)\end{array}$ & $\begin{array}{c}0.058 \\
(0.541)\end{array}$ & $\begin{array}{l}-0.019 \\
(0.036)\end{array}$ \\
\hline$\Delta \mathrm{ENEP}_{\mathrm{t}-1}$ & $\begin{array}{c}-0.469^{* *} \\
(0.146)\end{array}$ & $\begin{array}{c}-0.906^{* *} \\
(0.343)\end{array}$ & $\begin{array}{l}-0.026 \\
(0.028)\end{array}$ \\
\hline $\mathrm{ENEP}_{\mathrm{t}-2}$ & $\begin{array}{l}-0.187^{+} \\
(0.100)\end{array}$ & $\begin{array}{c}-0.406^{* *} \\
(0.149)\end{array}$ & $\begin{array}{l}-0.001 \\
(0.016)\end{array}$ \\
\hline Niche Party & $\begin{array}{c}0.538^{*} \\
(0.267)\end{array}$ & $\begin{array}{c}-0.589 \\
(0.402)\end{array}$ & $\begin{array}{c}-0.084^{* *} \\
(0.030)\end{array}$ \\
\hline Lagged DV & $\begin{array}{l}-0.095 \\
(0.432)\end{array}$ & $\begin{array}{c}-0.433^{* * *} \\
(0.062)\end{array}$ & $\begin{array}{r}-0.233^{* * * *} \\
(0.054)\end{array}$ \\
\hline Constant & $\begin{array}{l}-1.396^{*} \\
(0.584)\end{array}$ & $\begin{array}{l}7.702^{* * *} \\
(1.273)\end{array}$ & $\begin{array}{l}-0.072 \\
(0.086)\end{array}$ \\
\hline Time & $\begin{array}{c}0.010 \\
(0.017)\end{array}$ & & \\
\hline $\begin{array}{l}\text { Root Mean Squared } \\
\text { Error }\end{array}$ & & 3.948 & 0.374 \\
\hline $\begin{array}{l}\chi^{2} \\
\mathrm{~N}\end{array}$ & $\begin{array}{c}69.328 \\
775\end{array}$ & $\begin{array}{c}90.984 \\
775\end{array}$ & $\begin{array}{c}62.116 \\
768\end{array}$ \\
\hline
\end{tabular}




\begin{tabular}{lcc}
\hline & $(1)$ & $(2)$ \\
& ENMI & RILE \\
\hline \% Female MPst-1 & $2.296^{*}$ & $-0.301^{* *}$ \\
Female Leader ${ }_{\mathrm{t}-1}$ & $(1.012)$ & $(0.094)$ \\
& 0.079 & -0.021 \\
Incumbent $_{\mathrm{t}-1}$ & $(0.487)$ & $(0.045)$ \\
& -0.401 & 0.029 \\
Ideol. Distance & $(0.307)$ & $(0.028)$ \\
& -0.544 & 0.025 \\
\% Vote & $(0.553)$ & $(0.051)$ \\
& 0.003 & -0.000 \\
Majoritarian & $(0.012)$ & $(0.001)$ \\
& 0.522 & -0.056 \\
ENEP & $(0.403)$ & $(0.038)$ \\
& 0.015 & $-0.021^{+}$ \\
Niche Party & $(0.133)$ & $(0.012)$ \\
& -0.131 & -0.022 \\
Lagged DV & $(0.425)$ & $(0.039)$ \\
& $0.109^{* *}$ & $0.186^{* * *}$ \\
DV Varying & $(0.038)$ & $(0.037)$ \\
Equilibrium & $0.977^{* * *}$ & $1.080^{* * *}$ \\
Constant & $(0.037)$ & $(0.029)$ \\
& 0.217 & $0.158^{*}$ \\
Root Mean Squared & $(0.960)$ & $(0.066)$ \\
Error & 3.784 & 0.348 \\
N & & 768 \\
\hline
\end{tabular}


Table A3. Logistic Regression with Firth's Correction

(1)

Issue Entrep.

\begin{tabular}{lc} 
\% Female MPs & -0.374 \\
& $(1.401)$ \\
Female Leader & -0.161 \\
& $(0.710)$ \\
Incumbent & -0.226 \\
& $(0.374)$ \\
Ideol. Distance & -0.669 \\
& $(0.718)$ \\
\% Vote & 0.010 \\
& $(0.013)$ \\
ENEP & $-0.482^{*}$ \\
& $(0.214)$ \\
Lagged DV & -0.074 \\
& $(0.317)$ \\
Constant & -1.125 \\
& $(0.922)$ \\
\hline Log-Likelihood & -136.701 \\
$\chi^{2}$ & 15.099 \\
Observations & 899 \\
\hline
\end{tabular}




\begin{tabular}{|c|c|c|c|}
\hline & $\begin{array}{c}\text { (1) } \\
\text { Issue Entrep. }\end{array}$ & $\begin{array}{c}(2) \\
\text { ENMI }\end{array}$ & $\begin{array}{c}\text { (3) } \\
\text { RILE }\end{array}$ \\
\hline$\%$ Female MPs & $\begin{array}{l}-0.330 \\
(1.398)\end{array}$ & $\begin{array}{c}1.437 \\
(1.107)\end{array}$ & $\begin{array}{c}-0.452^{* * *} \\
(0.110)\end{array}$ \\
\hline Female Leader ${ }_{t-1}$ & $\begin{array}{l}-0.357 \\
(0.780)\end{array}$ & $\begin{array}{c}0.375 \\
(0.507)\end{array}$ & $\begin{array}{c}0.027 \\
(0.049)\end{array}$ \\
\hline Incumbent & $\begin{array}{l}-0.240 \\
(0.381)\end{array}$ & $\begin{array}{l}-0.003 \\
(0.328)\end{array}$ & $\begin{array}{l}-0.042 \\
(0.031)\end{array}$ \\
\hline Ideol. Distance ${ }_{t-1}$ & $\begin{array}{l}-0.783 \\
(0.727)\end{array}$ & $\begin{array}{c}0.287 \\
(0.571)\end{array}$ & $\begin{array}{c}0.039 \\
(0.056)\end{array}$ \\
\hline$\%$ Vote & $\begin{array}{c}0.011 \\
(0.013)\end{array}$ & $\begin{array}{l}0.058^{* *} \\
(0.018)\end{array}$ & $\begin{array}{l}-0.004^{+} \\
(0.002)\end{array}$ \\
\hline Majoritarian & $\begin{array}{c}0.072 \\
(0.417)\end{array}$ & $\begin{array}{c}1.270^{+} \\
(0.691)\end{array}$ & $\begin{array}{l}-0.138 \\
(0.088)\end{array}$ \\
\hline ENEP & $\begin{array}{l}-0.487^{*} \\
(0.220)\end{array}$ & $\begin{array}{l}-0.046 \\
(0.157)\end{array}$ & $\begin{array}{l}-0.041^{*} \\
(0.018)\end{array}$ \\
\hline Lagged DV & $\begin{array}{c}0.224 \\
(0.561)\end{array}$ & $\begin{array}{c}0.364^{* * *} \\
(0.032)\end{array}$ & $\begin{array}{c}0.359^{* * *} \\
(0.032)\end{array}$ \\
\hline Constant & $\begin{array}{l}-1.173 \\
(0.959)\end{array}$ & $\begin{array}{c}9.125^{* * *} \\
(1.032)\end{array}$ & $\begin{array}{l}-0.038 \\
(0.108)\end{array}$ \\
\hline Party-Level Std. Dev. & -14.217 & 0.350 & -1.422 \\
\hline Country-Level Std. Dev. & $\begin{array}{c}(455099.377) \\
-13.795\end{array}$ & $\begin{array}{c}(48.267) \\
0.350\end{array}$ & $\begin{array}{c}(11.895) \\
-1.422\end{array}$ \\
\hline Random Effect Constant & $(298383.562)$ & $\begin{array}{c}(48.267) \\
1.379^{* * *} \\
(0.027)\end{array}$ & $\begin{array}{c}(11.895) \\
-1.021^{* * *} \\
(0.027)\end{array}$ \\
\hline $\begin{array}{l}\chi^{2} \\
\text { Observations }\end{array}$ & $\begin{array}{c}16.960 \\
899\end{array}$ & $\begin{array}{c}184.683 \\
899\end{array}$ & $\begin{array}{c}185.543 \\
892\end{array}$ \\
\hline
\end{tabular}


Table A5. Models Controlling for Organizational Structure

\begin{tabular}{lccc}
\hline & $(1)$ & $(2)$ & $(3)$ \\
& Issue Entrep. & ENMI & RILE \\
\hline \% Female MPs & -0.805 & $5.868^{* *}$ & $-0.539^{* *}$ \\
\% Female MPs X & $(3.050)$ & $(2.189)$ & $(0.204)$ \\
Leader Hierarchy & $-11.882^{+}$ & -1.692 & -0.519 \\
& & & \\
Female Leader ${ }_{\text {t-1 }}$ & $(7.029)$ & $(4.306)$ & $(0.401)$ \\
& -0.285 & 1.050 & -0.071 \\
Incumbent & $(1.210)$ & $(0.803)$ & $(0.075)$ \\
& -0.276 & -0.229 & $-0.110^{* *}$ \\
Ideol. Distancet-1 & $(0.574)$ & $(0.455)$ & $(0.042)$ \\
& 1.830 & -0.335 & $0.194^{*}$ \\
\% Vote & $(1.133)$ & $(0.914)$ & $(0.085)$ \\
& 0.036 & 0.004 & 0.001 \\
Majoritarian & $(0.069)$ & $(0.048)$ & $(0.004)$ \\
& & $5.118^{* *}$ & $-0.543^{* * *}$ \\
ENEP & & $(1.615)$ & $(0.150)$ \\
& -0.211 & 0.367 & -0.030 \\
Lagged DV & $(0.649)$ & $(0.421)$ & $(0.039)$ \\
Constant & -15.515 & 0.076 & $0.143^{* *}$ \\
& $(1314.190)$ & $(0.050)$ & $(0.052)$ \\
\hline Log-Likelihood & & $11.193^{* * *}$ & 0.025 \\
Root Mean Squared & & $(2.340)$ & $(0.210)$ \\
Error & -40.889 & -1142.270 & -152.800 \\
$\chi^{2}$ & & 3.949 & 0.368 \\
Observations & 11.498 & & \\
\hline & 208 & 417 & 417 \\
\hline
\end{tabular}


Table A6. Models Controlling for Web 2.0

\begin{tabular}{|c|c|c|c|}
\hline & $\begin{array}{c}\text { (1) } \\
\text { Issue Entrep. }\end{array}$ & $\begin{array}{c}(2) \\
\text { ENMI }\end{array}$ & $\begin{array}{c}(3) \\
\text { RILE }\end{array}$ \\
\hline$\%$ Female MPs & $\begin{array}{l}-0.698 \\
(2.465)\end{array}$ & $\begin{array}{l}2.935^{*} \\
(1.448)\end{array}$ & $\begin{array}{c}-0.254^{+} \\
(0.131)\end{array}$ \\
\hline Female Leader $_{\mathrm{t}-1}$ & $\begin{array}{c}-0.973 \\
(1.134)\end{array}$ & $\begin{array}{l}1.214^{*} \\
(0.542)\end{array}$ & $\begin{array}{c}-0.002 \\
(0.049)\end{array}$ \\
\hline Incumbent & $\begin{array}{l}-0.355 \\
(0.471)\end{array}$ & $\begin{array}{l}-0.067 \\
(0.340)\end{array}$ & $\begin{array}{l}-0.060^{+} \\
(0.031)\end{array}$ \\
\hline Ideol. Distance $\mathrm{t}_{-1}$ & $\begin{array}{c}-0.076 \\
(0.790)\end{array}$ & $\begin{array}{l}-0.390 \\
(0.625)\end{array}$ & $\begin{array}{c}0.065 \\
(0.057)\end{array}$ \\
\hline$\%$ Vote $_{t-1}$ & $\begin{array}{c}0.066 \\
(0.051)\end{array}$ & $\begin{array}{c}0.039 \\
(0.032)\end{array}$ & $\begin{array}{l}-0.004 \\
(0.003)\end{array}$ \\
\hline Majoritarian & & $\begin{array}{l}4.370^{* *} \\
(1.528)\end{array}$ & $\begin{array}{c}-0.528^{* * * *} \\
(0.137)\end{array}$ \\
\hline $\mathrm{ENEP}_{\mathrm{t}-1}$ & $\begin{array}{l}-0.813 \\
(0.503)\end{array}$ & $\begin{array}{l}-0.040 \\
(0.262)\end{array}$ & $\begin{array}{l}-0.021 \\
(0.024)\end{array}$ \\
\hline Web 2.0 & $\begin{array}{l}0.990^{+} \\
(0.597)\end{array}$ & $\begin{array}{c}0.563 \\
(0.396)\end{array}$ & $\begin{array}{c}-0.210^{* * * *} \\
(0.036)\end{array}$ \\
\hline Lagged DV & $\begin{array}{l}-0.698 \\
(0.574)\end{array}$ & $\begin{array}{l}0.107^{* *} \\
(0.038)\end{array}$ & $\begin{array}{c}0.146^{* * *} \\
(0.035)\end{array}$ \\
\hline Constant & & $\begin{array}{c}12.787^{* * * *} \\
(1.620)\end{array}$ & $\begin{array}{c}-0.090 \\
(0.135)\end{array}$ \\
\hline $\begin{array}{l}\text { Log-Likelihood } \\
\text { Root Mean Squared } \\
\text { Error }\end{array}$ & -82.057 & $\begin{array}{c}-2429.659 \\
3.876\end{array}$ & $\begin{array}{c}-257.875 \\
0.347\end{array}$ \\
\hline
\end{tabular}




\section{BIBLIOGRAPHY}

Adams, James, Michael Clark, Lawrence Ezrow, and Garrett Glasgow. 2006. "Are Niche Parties Fundamentally Different from Mainstream Parties? The Causes and the Electoral Consequences of Western European Parties’ Policy Shifts, 1976-1998.” American Journal of Political Science 50(3):513-29.

Adams, James, and Zeynep Somer-Topcu. 2009. "Policy Adjustment by Parties in Response to Rival Parties' Policy Shifts: Spatial Theory and the Dynamics of Party Competition in Twenty-Five Post-War Democracies.” British Journal of Political Science 39(4):825-46.

de Vries, Catherine E., and Sara B. Hobolt. 2012. "When dimensions collide: The electoral success of issue entrepreneurs." European Union Politics 13(2): 246-268.

Ezrow, Lawrence. 2008. "Parties' Policy Programmes and the Dog That Didn't Bark: No Evidence That Proportional Systems Promote Extreme Party Positioning.” British Journal of Political Science 38(3):479.

Gibson, Rachel. 2012. 'From Brochureware to 'MyBo': An Overview of Online Elections and Campaigning." Politics 32(2): 77-84.

Greene, Zachary. 2015. "Competing on the Issues: How Experience in Government and Economic Conditions Influence the Scope of Parties' Policy Messages.” Party Politics OnlineFirst:1-14.

Jennings, Will, Shaun Bevan, Arco Timmermans, Gerard Breeman, Sylvain Brouard, Laura Chaqués-Bonafont, Christoffer Green-Pederson, Peter John, Peter Mortensen and Anna M. Palau. 2011. "Effects of the Core Functions of Government on the Diversity of Executive Agendas." Comparative Political Studies 44:1001-1030.

Jost, Lou. "Entropy and Diversity." Oikos 113, no. 2 (2006): 363-75.

Laakso, Markku, and Rein Taagepera. 1979. "Effective number of parties: A measure with application to West Europe." Comparative political studies 12(1): 3-27. 
Lowe, Will, Kenneth Benoit, Slava Mikhaylov, and Michael Laver. 2011. "Scaling Policy Preferences from Coded Political Texts." Legislative Studies Quarterly 36(1): 123-55.

McDonald, Michael D., and Robin Best. 2006. "Equilibria and restoring forces in models of vote dynamics." Political Analysis 14(4): 369-392.

Meguid, Bonnie M. 2008. Party Competition between Unequals: Strategies and Electoral Fortunes in Western Europe. Cambridge: Cambridge University Press.

Nyblade, Benjamin. 2004. "The 'Effective' Number of Issue Dimensions: A Measure with Application to West Europe." In Annual Meeting of the Midwest Political Science Association, April, 15-18.

Schumacher, Gijs, Catherine E. de Vries, and Barbara Vis. 2013. "Why Do Parties Change Position? Party Organization and Environmental Incentives." The Journal of Politics 75(02):464-77.

Shannon, Claude E. 1948. "A Note on the Concept of Entropy.” Bell System Tech. J 27: 379-423.

Stoll, Heather. 2011. "Dimensionality and the Number of Parties in Legislative Elections." Party Politics 17(3): 405-29.

Wagner, Markus. 2012. “When Do Parties Emphasise Extreme Positions? How Strategic Incentives for Policy Differentiation Influence Issue Importance." European Journal of Political Research 51(1):64-88. 